\title{
工場持込時生乳における低温細菌群
}

\author{
(昭和 50 年 4 月 18 日受理)
}

\author{
日越 博 信* 浜田輔 一*

\section{Studies on the Psychrotrophic Bacteria of Dairy Plant Milk} \\ Hironobu HigoshI and Sukekazu HamaDA \\ (Department of Veterinary Public Health, Faculty of Veterinary Medicine, \\ Hokkaido University: Kita 18 jo Nishi 9-chome, Kita-ku, Sapporo)
}

The conditions of contamination with bacteria grown at $5^{\circ} \mathrm{C}$ for 10 days, $20^{\circ} \mathrm{C}$ for 4 days, and $35^{\circ} \mathrm{C}$ for 2 days incubations of raw milk obtained at 2 dairy plants, were studied on 563 samples. After that, 393 strains isolated at $5^{\circ} \mathrm{C}$ incubation from raw milk, 302 strains at $20^{\circ} \mathrm{C}$ and 362 strains at $35^{\circ} \mathrm{C}$ were identified and were tested their growth abilities at $0^{\circ} \mathrm{C}$ for 14 days, $5^{\circ} \mathrm{C}$ for 10 days, $20^{\circ} \mathrm{C}$ for 4 days, and $35^{\circ} \mathrm{C}$ for 2 days incubations respectively.

The results obtained are summarized as follows:

1) Bacterial counts of most of raw milk samples were ranged from the level of $10^{3} /$ $\mathrm{ml}$ to $10^{8} / \mathrm{ml}$ at $5^{\circ} \mathrm{C}$ incubation, and, from the level of $10^{4} / \mathrm{ml}$ to $10^{8} / \mathrm{ml}$ at both 20 and $35^{\circ} \mathrm{C}$ incubations. The number of samples with bacterial counts more than $10^{6} / \mathrm{ml}$ was many at $20^{\circ} \mathrm{C}$ incubation, without the distinctions of season and milking method. On comparison of bacterial counts of samples from hand-milking and milker-milking, their bacterial counts differed in area and season. But it showed a tendency that the number of samples with bacterial counts more than $10^{6} / \mathrm{ml}$ was many in milker-milking.

2) Total strains of gram-negative bacilli such as Pseudomonas, coliform bacteria, Flavobacterium etc. occupied $80.8 \%$ of all strains isolated at $5^{\circ} \mathrm{C}$ incubation of raw milk. In strains isolated at $20^{\circ} \mathrm{C}$ incubation, total strains of gram-negative bacilli such as Flavobacterium, coliform bacteria, Pseudomonas etc. were $69.0 \%$. On the other hand, in strains isolated at $35^{\circ} \mathrm{C}$ incubation, total strains of cocci consisted of Streptococcus mostly were $55.2 \%$, and gram-negative bacilli were only $30.7 \%$.

3) Out of 393 strains isolated at $5^{\circ} \mathrm{C}$ incubation, all but one were well grown at $20^{\circ} \mathrm{C}$ in growth-test. One hundred and ninety six strains $(64.9 \%)$ of 302 strains isolated at $20^{\circ} \mathrm{C}$ incubation were well grown at $5^{\circ} \mathrm{C}$. Ninety five point nine percent of 362 strains isolated at $35^{\circ} \mathrm{C}$ incubation was well grown at $20^{\circ} \mathrm{C}$.

4) The method at $20^{\circ} \mathrm{C}$ for 4 days incubation is supposed as more superior than the one at $35^{\circ} \mathrm{C}$ for 2 days incubation to estimate the viable bacterial counts including both psychrotrophs and mesophiles in raw milk, especially in raw milk arrived at milk plant.

(Received April 18, 1975)

著者らは, 生乳の低温細菌群による污染の穾態を調査 し，生乳由来本細菌群の種々の性状について検討してき た，そして前報告1)では，乳牛分房から採取した生乳 （分房生乳）について，大多数例で菌数そのものは少な かったが，をた分離された大多数株が Micrococcus を 主体とする球菌類拉よびグラム陽性桿菌類とはい方，

* 北海道大学獣医学部：札幌市北区北 18 条西 9 丁目
でに低温細菌群によっても污染されていることを, 記述 した.

今回は, 特に対象として前報告の分房生乳試料を採取 した酪農家の工場持込時生乳（工場生乳）の個々につい て，前報と同様に 5,20 , 抢上び $35^{\circ}$ に打ける生菌数を測 定し，次いでそれぞれから分離した菌株について同定拉 よび $0,5,20,35^{\circ}$ での発育試験を行い, 分房生乳での成 績と比較考察した．以下これらについて報告する. 


\section{材料および方法}

\section{1. 供試材料}

前報の分房生乳を採取した 3 地区のうち，江別（1964 年5 6月）挔よび角山の 2 地区酪農家を, 前回同様に手 竹乳群とミルカー㩁乳群とに分け, また角山地区の酪農 家については秋季 (1965年9 10月) おょび冬季 (1966年 1 2月）の 2 回採取し, 延 136 戸の工場生乳合計 563 試 料を得た。

\section{2. 生菌数の測定と菌株の分離}

生菌数の測定方法怙よび菌株の分離方法はすべて前回 と同様であり, $5^{\circ}$ では 393 株, $20^{\circ}$ では 302 株, $35^{\circ}$ では 362株を分離した。

\section{3. 分離菌株の同定}

前報の分房生乳からの分離菌株の場合と全く同様の基 準に従って同定した.

\section{4 種温度における発育試験}

供試菌は $0.5 \%$ 酵母エキス寒天培地平板上に移植後そ

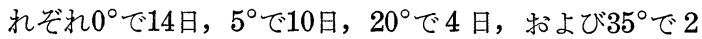
日培養して, 発育状態を観察した。

\section{成績}

3 種の培養温度別菌数の出現状況を Table 1 に示し た。

$5^{\circ}$ 培養菌数は多くの試料で $10^{3} \sim 10^{6}$ 台であった． 20 お よび $35^{\circ}$ 培養菌数では $10^{4} \sim 10^{6}$ 台を示した例が多かった
が， $20^{\circ}$ 培養では $10^{7}$ 台の例がやや多かった。

3 種の培養温度別菌数の出現状態を竹乳方法別にみる と, 江別地区未よび $5^{\circ}$ 培養を除く角山地区秋季試料で は, 手搾乳群に比べてミルカー搾乳群の方に $10^{6}$ 以上を 示す例数の出現率が高かったが，角山地区冬季試料で は, 手㩁乳群とミルカー搾乳群とのそれらの出現率は 3 種培養共に相似ていた.な和角山地区の冬季試料では, 秋季試料に比べて生菌数の多い傾向がみられた.

次に個々試料に打汀る 3 種培養温度別菌数の出現状態 の相互関係をみると，Table 2 のようになる.

$5^{\circ}$ 培養菌数と $35^{\circ}$ 培養菌数とでは, 江別地区ミルカー 搾乳群を除いて, $35^{\circ}$ 培養菌数の多い例数百分率が高か った. この傾向は, 角山地区では季節に関係なく, 手搾 乳群よりミルカー㩁乳群で著明であった. 5 培養菌数と $20^{\circ}$ 培養菌数とでは, 角山地区に打いて季節または搾乳 方法に関係なく, $20^{\circ}$ 培養菌数の多い例数百分率が圧倒 的に高かった. $20^{\circ}$ 培養菌数と $35^{\circ}$ 培養菌数とでは, 多く

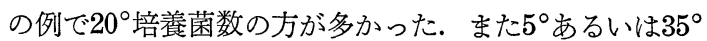
培養菌数よりも, $20^{\circ}$ 培養菌数の方が多い例数百分率は, 手搾乳群, ミルカ一搾乳群共に秋季よりも冬季試料に高 かった.

\section{分離菌株の同定}

$5^{\circ}$ 分離菌 393 株, $20^{\circ}$ 分離菌 302 株抢よび $35^{\circ}$ 分離菌 362株について行った同定の成績を, Table 3 に示した.

Table 1. Incidence of Bacterial Counts of Raw Milk Samples from Milk Plant at 5, 20, and $35^{\circ} \mathrm{C}$ Incubations, According to Areas and Milking Methods

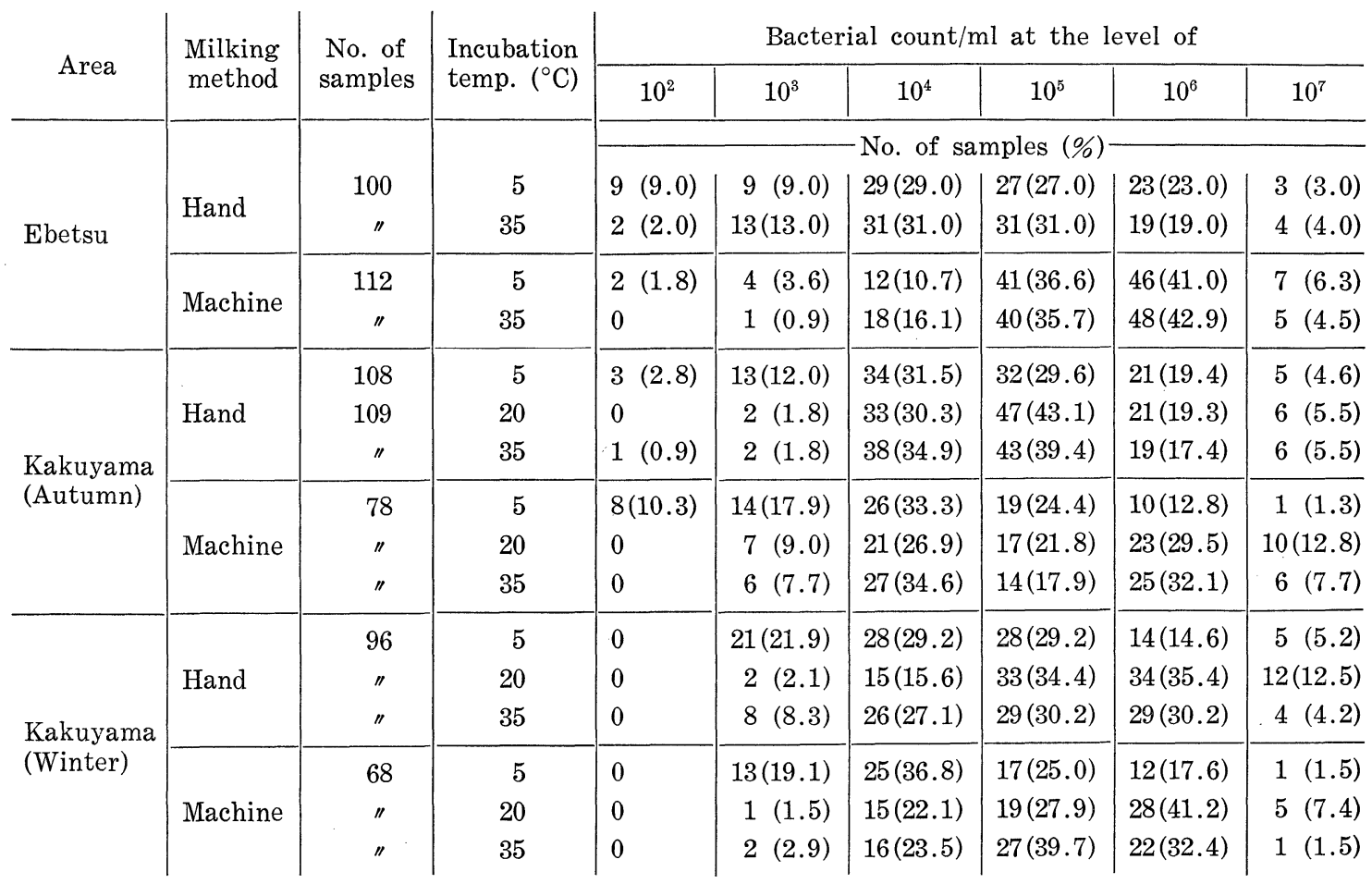


Table 2. Comparison of Bacterial Counts of Plant Raw Milk Samples at 5, 20, or $35^{\circ} \mathrm{C}$ Incubations

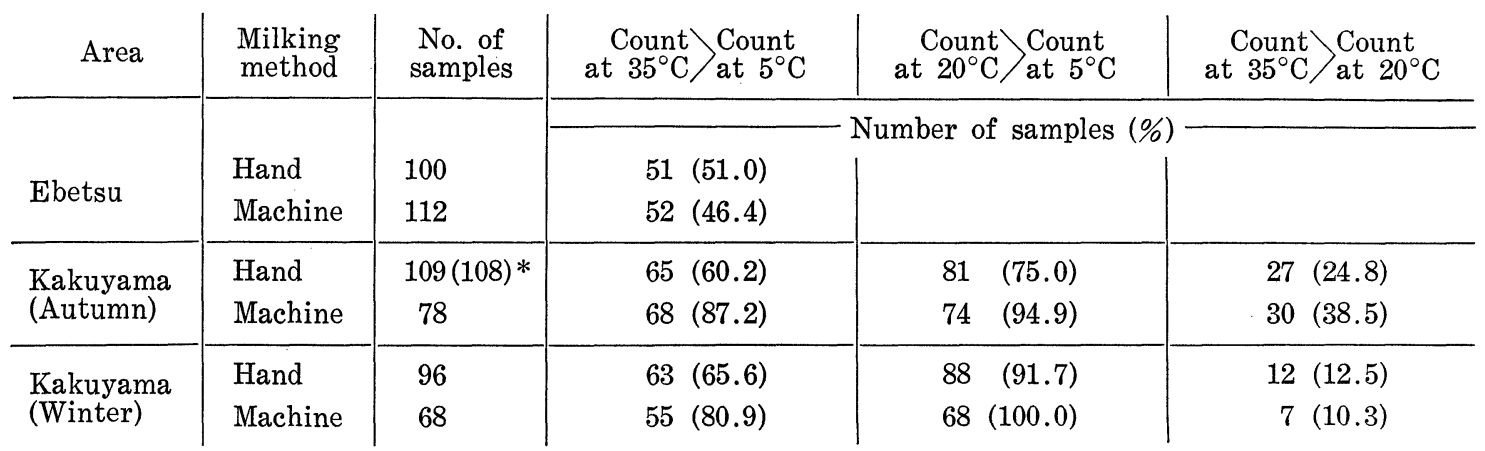

* Number in parenthesis indicates No. of samples examined at $5^{\circ} \mathrm{C}$

Table 3. Incidence of Organisms Isolated from Plant Raw Milk Samples at 5, 20, and $35^{\circ} \mathrm{C}$ Incubations

\begin{tabular}{|c|c|c|c|}
\hline \multirow{2}{*}{$\begin{array}{l}\text { Organism } \\
\text { isolated }\end{array}$} & \multicolumn{3}{|c|}{ Incubation temperature } \\
\hline & $5^{\circ} \mathrm{C}$ & $20^{\circ} \mathrm{C}$ & $35^{\circ} \mathrm{C}$ \\
\hline Pseudomonas & $80(20.4)^{* 1}$ & $31(10.3)$ & $5(1.4)$ \\
\hline Flavobacterium & $55(14.0)$ & $45(14.9)$ & $13(3.6)$ \\
\hline $\begin{array}{l}\text { Alcaligenes } \\
\text { Achromobacter }\end{array}$ & $15(3.8)$ & $28(9.3)$ & $10(2.8)$ \\
\hline Acinetobacter & $39(9.9)$ & $2(0.7)$ & 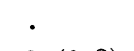 \\
\hline Aeromonas & $2(0.5)$ & $9(3.0)$ & $3(0.8)$ \\
\hline Coliform bacteria & $63(16.0)$ & $44(14.6)$ & $56(15.5)$ \\
\hline Staphylococcus & $2(0.5)$ & $10(3.3)$ & $32(8.8)$ \\
\hline Micrococcus & $31 \quad(7.9)$ & $15(4.9)$ & $70(19.3)$ \\
\hline Streptococcus & $14(3.6)$ & $29(9.6)$ & $75(20.7)$ \\
\hline Bacillus & $* 2$ & . & $7(1.9)$ \\
\hline Yeast & $2(0.5)$ & . & - \\
\hline Unclassified & & & \\
\hline Gram $(-)$ rods & $64(16.2)$ & $49(16.2)$ & $24(6.6)$ \\
\hline $\operatorname{Gram}(+)$ rods $* 3$ & $23(5.9)$ & $22(7.3)$ & $44(12.2)$ \\
\hline $\operatorname{Gram}(+) \operatorname{cocci}$ & $3(0.8)$ & $18(5.9)$ & $23(6.4)$ \\
\hline Total & $\beta 93$ & $2(100.0$ & $362(100.0)$ \\
\hline
\end{tabular}

*1 Number in parenthesis indicates percentage.

*2 .: Zero.

*3 Including coryneform bacteria.

5 分離菌株では，Pseudomonas $(20.4 \%)$ が最も多 く, 次いで非同定グラム陰性桿菌, 大腸菌群, Flavobacterium などの順であり，これらグラム陰性桿菌類 が全体の $80.8 \%$ を占めた. $20^{\circ}$ 分離菌株でもグラム院性 桿菌類は多かったが，その出現率は $69.0 \%$ と $5^{\circ}$ 分離菌株 に比べて低く, 乙かも出現率順位も変わって, 非同定グ
ラム陰性桿菌, Flavobacterium, 大腸菌群, Pseudomonas などの順となり, 他方, Streptococcus が増え た. $35^{\circ}$ 分離菌株では, 大腸菌群の出現率は前 2 者と注 とんど変わらなかったが，全グラム陰性桿菌類は $30.7 \%$ にすぎず, 代わって Streptococcus, Micrococcus, Staphylococcus などの球菌類が増加して $55.2 \%$ に達し た.な和前報の分房生乳由来株を含む生乳由来の Pseudomonas では, $5^{\circ}$ 分離の $71 \%$ 拈よび $20^{\circ}$ 分離の 62\%が，それぞれけい光性色素を産生した。

\section{分離菌株の 4 種の温度での発育}

同定を行った全分離菌株について， $0^{\circ} ， 14$ 日； $5^{\circ} ， 10$ 日； $20^{\circ}, 4$ 日, 抢よび $35^{\circ}, 2$ 日培養での発育状態を観察し た.

Table 4 亿示されるように，5分離菌393株では， $20^{\circ}$ 4 日以内に 1 株を除くすべてが発育し，乙かも注とんど の菌株が良好に発育した。 0 ○では $24.4 \%$ の菌株が発育し なかったが，これらは Aeromonas, 非同定グラム陽性 球菌, Micrococcus, Staphylococcus, Streptococcus などに多かった。 また $35^{\circ}$ では $34.4 \%$ の菌株が発育しな かったが，これらの多くは Flavobacterium, Acinetobacter などであった. な执大腸菌群および Pseudomonas では, 他の菌属に比べて，4種の温度共に良好 に発育した菌株が多かった.

次は $20^{\circ}$ 分離菌 302 株の発育状態を, Table 5 に示し た.

$0^{\circ}$ では $59.6 \%$ の菌株が発育しなかったが，この数值は $5^{\circ}$ 分離菌株の $20.4 \%$ に比べて著しく多かった． $5^{\circ}$ では $35.1 \%$ の菌株が発育しなかった。これらは球菌類, 特に Streptococcus に多かったが, 他方 Alcaligenes-

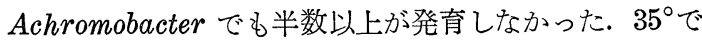
は $15.2 \%$ の菌株が発育しなかったが，これらの多くは Flavobacterium であった.

次に $35^{\circ}$ 分離菌 362 株の発育状態を, Table 6 に示し た。 
Table 4. Degree of Growth at Different Incubation Temperatures of Organisms Isolated at $5^{\circ} \mathrm{C}$ from Plant Raw Milk Samples

\begin{tabular}{|c|c|c|c|c|c|c|c|c|c|c|c|c|c|c|c|}
\hline \multirow{3}{*}{$\begin{array}{l}\text { Organism } \\
\text { isolated }\end{array}$} & \multirow{3}{*}{$\begin{array}{l}\text { No. of } \\
\text { strains } \\
\text { examined }\end{array}$} & \multicolumn{14}{|c|}{ Incubation temperature and degree ${ }^{* 1}$ of growth } \\
\hline & & \multicolumn{3}{|c|}{$0^{\circ} \mathrm{C}$} & \multicolumn{4}{|c|}{$5^{\circ} \mathrm{C}$} & \multicolumn{3}{|c|}{$20^{\circ} \mathrm{C}$} & \multicolumn{4}{|c|}{$35^{\circ} \mathrm{C}$} \\
\hline & & - & + & H H & - & + & H & 世 & - & $\dot{+}$ & H $\#$ & - & + & $H$ & H \\
\hline Pseudomonas & 80 & 4 & 2 & $7 \quad 67$ & $\cdot$ & 2 & . & 78 & . & . & . 80 & 17 & 16 & 1 & 46 \\
\hline Flavobacterium & 55 & 14 & 1 & $3 \quad 37$ & 3 & 4 & 3 & 45 & . & . & 154 & 33 & 8 & 2 & 12 \\
\hline $\begin{array}{l}\text { Alcaligenes } \\
\text { Achromobacter }\end{array}$ & 15 & 3 & 2 & 28 & 1 & 2 & 2 & 10 & & . & . 15 & 8 & . & 2 & 5 \\
\hline Acinetobacter & 39 & 8 & 1 & 129 & 1 & 2 & 7 & 29 & 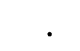 & . & 237 & 23 & 2 & . & 14 \\
\hline Aeromonas & 2 & 2 & . & . & . & . & 1 & 1 & . & . & . 2 & . & . & . & 2 \\
\hline Coliform bacteria & 63 & 7 & 1 & $3 \quad 52$ & . & 2 & 5 & 56 & $\cdot$ & . & . 63 & 2 & . & . & 61 \\
\hline Staphylococcus & 2 & 1 & 1 & . & . & 1 & 1 & 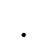 & . & . & . 2 & . & . & $\cdot$ & 2 \\
\hline Micrococcus & 31 & 16 & 3 & 210 & . & 5 & 12 & 14 & . & . & . 31 & 3 & 1 & 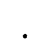 & 27 \\
\hline Streptococcus & 14 & 6 & 5 & 21 & 7 & 5 & 2 & . & 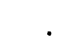 & 11 & 21 & 2 & 11 & . & 1 \\
\hline Yeast & 2 & **4 & 1 & . & . & 1 & . & 1 & . & . & . & . & . & 2 & \\
\hline \multicolumn{16}{|l|}{ Unclassified } \\
\hline $\operatorname{Gram}(-)$ rods & 64 & 12 & 1 & 348 & 1 & 3 & 6 & 54 & . & . & . 64 & 34 & 4 & 5 & 21 \\
\hline $\operatorname{Gram}(+)$ rods*2 & 23 & 5 & 3 & $4 \quad 11$ & 4 & 2 & 3 & 14 & . & 1 & 121 & 12 & 3 & 3 & 5 \\
\hline $\operatorname{Gram}(+)$ cocci & 3 & 2 & 1 & . & 2 & 1 & . & . & 1 & . & . 2 & 1 & . & . & 2 \\
\hline Total & 393 & $\begin{array}{c}80 \\
(20.4)\end{array}$ & & 27264 & $\begin{array}{c}19 \\
(4.8)\end{array}$ & 30 & 423 & & $\begin{array}{c}1 \\
(0.3)\end{array}$ & 12 & 6374 & $\begin{array}{l}135 \\
(34.4\end{array}$ & & & 198 \\
\hline
\end{tabular}

*1 Degree of growth: -, no growth; +, poor growth; $\#$, moderate growth; H, good growth

*2 Including coryneform bacteria

*3 Number in parenthesis indicates percentage

*4 .: Zero

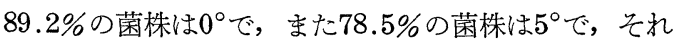
ぞれ発育せず, これらの数値は $20^{\circ}$ 分離菌株のそれらに 比べて著しく高かった．さらに $20^{\circ}$ でも発育しなかった 菌株が $4.1 \%$ あった.

考察

工場生乳に括汀る生菌数は, 前報1) の分房生乳に和け るそれに比べて， $5 ， 20 ，$ 抢よび $35^{\circ}$ の 3 種の温度培養共 に著しく多かった，搾乳後から工場利着までの過程を調 査していないのでこの污染源を具体的には指摘できな い. 乙かし江別地区分の工場到着時の生乳温度は8 $21^{\circ}$ もあった．これらはそのとさの外気温とほぼ等しく, こ れらの生乳温度では低温細菌ばかりが中温細菌でさ光短 時間で增殖できるから，生乳の冷却不十分も菌数増加の 一原因と考光られる.

Desai \& Claydon ${ }^{22}$ によれば, 冬季試料で低温細菌数 が多いのに対し, 夏季試料で中温細菌数が多いのは, 外 気温による影響という。これに対して著者らの成績で は, 角山地区の冬季試料は同秋季試料に比べて，3 種の 培養温度別菌数共に多くなる傾向を示したが，この理由 の一つに, 冬季に打けるミルカーまたは酪農機具類の洗
浄・消毒の不完全が考兄られる.

江別地区のミルカー搾乳群では, 手搾乳群に比べて, 菌数の多い例数出現率が高かったが，これは白坂と久池 $\#^{3)}$, 宮沢 ${ }^{4)}$, 小川 ${ }^{5)}$ の成績ともほぼ一致する. 角山地 区秋季試料でも， $5^{\circ}$ 培養菌数を除くと，江別地区と同様 の傾向を示したが，同冬季試料ではミルカー搾乳群と手 搾乳群とが，3 種の培養温度別菌数ともに注涪同様の出 現状沉を示した。このようにミルカー㩁乳または手搾乳 いずれの搾乳方法が，細菌学的に良い生乳を供給するか 否かは，地区により，また同一地区でも季節によって異 なるよらである。

工場生乳の 3 種の温度別培養菌数は, 分房生乳のそれ らに比べて，相互により接近していた．小川占は，工場 生乳では低温細菌数と中温細菌数とがほぼ等しいと報告 したが，著者らの成績では汇別地区のミルカー搾乳群の みでこの傾向がみられた．しかし大多数例では，5培養 菌数よりも 35 または $20^{\circ}$ 培養菌数の方が多く, Prouty ${ }^{6)}$ のバルクタンク乳に执ける成績とほぼ一致した。一方, $20^{\circ}$ 培養菌数は多くの例で $35^{\circ}$ 培養菌数よりも多からた.

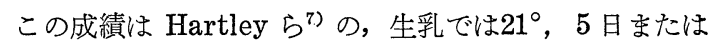


Table 5. Degree of Growth at Different Incubation Temperatures of Organisms Isolated at $20^{\circ} \mathrm{C}$ from Plant Raw Milk Samples

\begin{tabular}{|c|c|c|c|c|c|c|c|c|c|c|c|c|c|c|c|c|c|}
\hline \multirow{3}{*}{$\begin{array}{c}\text { Organism } \\
\text { isolated }\end{array}$} & \multirow{3}{*}{$\begin{array}{c}\text { No. of } \\
\text { strains } \\
\text { examined }\end{array}$} & \multicolumn{16}{|c|}{ Incubation temperature and degree ${ }^{* 1}$ of growth } \\
\hline & & \multicolumn{4}{|c|}{$0^{\circ} \mathrm{C}$} & \multicolumn{4}{|c|}{$5^{\circ} \mathrm{C}$} & \multicolumn{4}{|c|}{$20^{\circ} \mathrm{C}$} & \multicolumn{4}{|c|}{$35^{\circ} \mathrm{C}$} \\
\hline & & -+ & + & H & H & - & + & H & $H$ & - & + & H & 世 & - & + & H & H \\
\hline Pseudomonas & 31 & 10 & 2 & 2 & 17 & 5 & 6 & 1 & 19 & . & . & 2 & 29 & 6 & 1 & 4 & 20 \\
\hline Flavobacterium & 45 & 15 & 4 & 2 & 24 & 8 & 4 & 5 & 28 & . & 1 & . & 44 & 23 & 2 & 5 & 15 \\
\hline $\begin{array}{l}\text { Alcaligenes } \\
\quad \text { Achromobacter }\end{array}$ & 28 & 27 & . & 1 & . & 15 & 10 & 2 & 1 & . & . & . & 28 & 1 & 7 & 4 & 16 \\
\hline Acinetobacter & 2 & $* 4$ & : & 1 & 1 & . & . & . & 2 & . & . & . & 2 & 1 & . & . & 1 \\
\hline Aeromonas & 9 & . & 2 & 3 & 4 & . & . & 1 & 8 & . & . & . & 9 & . & . & . & 9 \\
\hline Coliform bacteria & 44 & 16 & 1 & 5 & 22 & 3 & 4 & 5 & 32 & . & . & . & 44 & . & . & 1 & 43 \\
\hline Staphylococcus & 10 & 7 & 3 & . & . & 4 & 1 & 3 & 2 & . & ${ }^{\circ}$ & . & 10 & . & . & . & 10 \\
\hline Micrococcus & 15 & 8 & 5 & 1 & 1 & 6 & • & 3 & 6 & . & . & . & 15 & 1 & . & . & 14 \\
\hline Streptococcus & 29 & 27 & 2 & $\cdot$ & $\cdot$ & 26 & 3 & . & • & . & 22 & 6 & 1 & 5 & 22 & 1 & 1 \\
\hline \multicolumn{18}{|l|}{ Unclassified } \\
\hline $\operatorname{Gram}(-) \operatorname{rods}$ & 49 & 39 & 2 & 2 & 6 & 18 & 15 & 6 & 10 & . & . & 2 & 47 & 3 & 7 & 5 & 34 \\
\hline $\operatorname{Gram}(+)$ rods*2 & 22 & 17 & 5 & . & . & 11 & 3 & 3 & 5 & . & 2 & 2 & 18 & 4 & 2 & . & 16 \\
\hline $\operatorname{Gram}(+) \operatorname{cocci}$ & 18 & 14 & 3 & . & 1 & 10 & 5 & 2 & 1 & . & 2 & . & 16 & 2 & 2 & 1 & 13 \\
\hline Total & 302 & $\begin{array}{c}180 \\
(59.6)^{2}\end{array}$ & 29 & 17 & 76 & $\begin{array}{l}106 \\
(35.1)\end{array}$ & & & 114 & $(0 . \dot{0})$ & 27 & & & $\begin{array}{c}46 \\
(15.2)\end{array}$ & & & 192 \\
\hline
\end{tabular}

*1 Degree of growth: -, no growth; +, poor growth; H, moderate growth: W, good growth

*2 Including coryneform bacteria

*3 Number in parenthesis indicates percentage

*4 . : Zero

$28^{\circ} ， 4$ 日培養菌数が多く出現した，といら報告に相通 じるものがある. 以上の成績から判断すると, 従来の 30 $\sim 37^{\circ}, 2$ 日培養による一般生菌数測定法 では, 工場生 乳のよらな試料に多く含まれる低温細菌が，見落される 恐れが多分にある，と推察される.

低温細菌群のらちで Pseudomonas が優勢であるとす る報告は多(8) 11). 著者らの成績でもこれら研究者の成 績と同様に，50分離菌株ではP Seudomonas が最も多か った. 非同定株を除くと, 次に大腸菌群 (16.0\%) が多 く,この出現率は Panes \& Thomas ${ }^{12)}$ の総説で紹介さ れた 5〜20\%の範囲内にあった。この大腸菌群は, 低温 での発育能を有することから, 冷蔵保存生乳の品質低下 に関して, Pseudomonas に次いで重要な存在と思われ る. これらを含さグラム陰性桿菌類は工場生乳の5 ${ }^{\circ}$ 分離 菌株で優勢であったが，これらは単に搾乳後の污染によ るものばかりでなく，すでに分房生乳にも存在したそれ ら1) が増加した分もあると考劣られる.

一方, $20^{\circ}$ 分離菌株では, グラム陰性桿菌類が多いと いう点で, $35^{\circ} よ り も 5^{\circ}$ 分離菌株の出現状況に近かった. この成績は, 前報の分房生乳では 3 種の培養温度を通し て球菌類が多かったこと, また $20^{\circ}$ 分離菌株の出現状況
が5゚よりも $35^{\circ}$ 分離菌株のそれに近かったこととは，大 いに異なった.

他方，温度別の発育試験に打いて，5分離菌株では 1 株を除くすべてが $20^{\circ} ， 4$ 日で発育し，乙かも大多数株 の発育が良好であった.これと同様の成績は分房生乳の 菌株でも得られたことから，これらのことは，多くの低 温細菌群の至適発育温度が $20^{\circ}$ 付近にあることを裏付け ているかもしれない. $20^{\circ}$ 分離の工場生乳の菌株では分 房生乳の菌株に比較して，0○で発育した株が多かったの に対し，35○で発育した株が少なかった。これは分房生 乳の菌株では $35^{\circ}$ で発育し， $0^{\circ}$ で発育しない球菌類が多 かったのに対し, 工場生乳の菌株では $0^{\circ}$ で発育し, $35^{\circ}$ で発育しないグラム陰性桿菌類が多かったことを反映し ている.

$20^{\circ}$ 分離菌株では約 $2 / 3$ が $5^{\circ}, 10$ 日以内に発育し, ま たこれとほぼ同様の成績が分房生乳の $20^{\circ}$ 分離菌株（約 4/5) でも得られたことから，これらは低温細菌群に入れ られることになる。したがって分離菌株に抢けるこれら の発育試験成績から，20，4 日培養法は低温細菌群検 出の迅速法として役立ちそうである. さらに $35^{\circ}$ 分離菌 株は，5○では大多数株が発育しなかったが，20ではほ 
Table 6. Degree of Growth at Different Incubation Temperatures of Organisms Isolated at $35^{\circ} \mathrm{C}$ from Plant Raw Milk Samples

\begin{tabular}{|c|c|c|c|c|c|c|c|c|c|c|c|c|c|c|c|c|c|}
\hline \multirow{3}{*}{$\begin{array}{c}\text { Organism } \\
\text { isolated }\end{array}$} & \multirow{3}{*}{$\begin{array}{c}\text { No. of } \\
\text { strains } \\
\text { examined }\end{array}$} & \multicolumn{16}{|c|}{ Incubation temperature and degree ${ }^{* 1}$ of growth } \\
\hline & & \multicolumn{4}{|c|}{$0^{\circ} \mathrm{C}$} & \multicolumn{4}{|c|}{$5^{\circ} \mathrm{C}$} & \multicolumn{4}{|c|}{$20^{\circ} \mathrm{C}$} & \multicolumn{4}{|c|}{$35^{\circ} \mathrm{C}$} \\
\hline & & - & + & H & H & - & + & $H$ & $H$ & - & + & H & H & - & + & H & 世 \\
\hline Pseudomonas & $5(5) * 2$ & 5 & . & . & . & 5 & . & . & . & . & . & . & 5 & . & . & 1 & 4 \\
\hline Flavobacterium & $13(13)$ & 13 & . & . & . & 12 & . & . & 1 & . & . & . & 13 & . & . & 3 & 10 \\
\hline $\begin{array}{l}\text { Alcaligenes } \\
\quad \text { Achromobacter }\end{array}$ & $10(6)$ & 6 & - & . & . & 7 & 3 & . & $\cdot$ & . & $\cdot$ & 4 & 6 & $\cdot$ & · & 2 & 8 \\
\hline Aeromonas & $3(2)$ & $* 4$ & . & . & 2 & . & . & . & 3 & . & . & . & 3 & . & . & . & 3 \\
\hline Coliform bacteria & $56(51)$ & 35 & . & 5 & 11 & 19 & 6 & 9 & 22 & . & . & 1 & 55 & . & . & . & 56 \\
\hline Staphylococcus & $32(28)$ & 27 & 1 & . & $\cdot$ & 26 & 2 & 3 & 1 & 3 & 1 & 4 & 24 & . & . & 3 & 29 \\
\hline Micrococcus & $70(57)$ & 48 & 7 & . & 2 & 56 & 4 & 3 & 7 & 2 & 7 & 9 & 52 & . & 1 & 5 & 64 \\
\hline Streptococcus & $75(65)$ & 65 & . & . & $\cdot$ & 71 & 4 & . & . & 5 & 65 & 5 & . & . & 70 & 5 & . \\
\hline Bacillus & $7(3)$ & 3 & . & . & . & 5 & . & . & 2 & . & . & . & 7 & . & . & . & 7 \\
\hline \multicolumn{18}{|l|}{ Unclassified } \\
\hline $\operatorname{Gram}(-) \operatorname{rods}$ & $24(21)$ & 20 & 1 & $\cdot$ & . & 22 & 1 & . & 1 & . & . & 2 & 22 & . & . & 5 & 19 \\
\hline $\operatorname{Gram}(+)$ rods $* 3$ & $44(21)$ & 19 & . & . & 2 & 40 & 2 & 1 & 1 & 1 & 4 & 5 & 34 & . & 3 & 4 & 37 \\
\hline $\operatorname{Gram}(+) \operatorname{cocci}$ & $23(15)$ & 15 & . & . & . & 21 & 2 & . & . & 4 & 3 & 4 & 12 & . & 2 & 6 & 15 \\
\hline Total & $362(287)$ & $\begin{array}{l}256 \\
(89.2 \%\end{array}$ & & 5 & 17 & $\begin{array}{l}284 \\
(78.5\end{array}$ & & 16 & 38 & $\begin{array}{c}15 \\
(4.1 \%\end{array}$ & $\begin{array}{l}80 \\
\text { b) }\end{array}$ & 34 & 233 & $(0$. & & 34 & 252 \\
\hline
\end{tabular}

*1 Degree of growth: -, no growth; +, poor growth; H, moderate growth; H, good growth

*2 Number in parenthesis indicates No. of strains examined at $0^{\circ} \mathrm{C}$

*3 Idcluding coryneform bacteria

*4. : Zero

とんぞの株が発育したこと，また前記 $20^{\circ}$ 分離菌株の大 多数株が $35^{\circ}$ で発育したことを併わせ考慮すると， $20^{\circ}$ ， 4 日培養法は, 低温細菌群拉よび中温細菌群の両者を包 含し得る培養法と考只られる. 実際に多くの工場生乳の $20^{\circ}$ 培養菌数は $35^{\circ}$ 培養菌数よりも多かった. したがって 特に中温細菌群のみならず低温細菌群にも污染されてい る生乳の生菌数を, より実態に近い数で推定する方法と

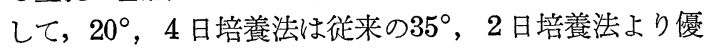
れていると思われる。

\section{要 約}

前報の分房生乳を採取した酪農家を含む延 136 戸の工

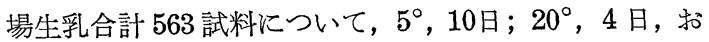
よび $35^{\circ} ， 2$ 日培養の生菌数を測定し，次いでこれらの それぞれから分離した 1,057 菌株について, 同定を行 いまた $0 ， 5 ， 20 ，$ 抢よび $35^{\circ}$ での発育を検討し，次の 成績を得た。

1）工場生乳に打ける生菌数は, $1 \mathrm{ml}$ 当たり $5^{\circ}$ 培養 では $10^{3} \sim 10^{6}$ 台, 20 および $35^{\circ}$ 培養では $10^{4} \sim 10^{6}$ 台の例 数が多かった. 㩁乳方法別の比較では, 地区によって, また同一地区でも季節によって生菌数の出現状沉が異な った. 冬季試料では秋季試料に比べて, $10^{6}$ 以上の例数
の出現率が高い傾向を示した。

2） $5^{\circ}$ 培養菌数は， $35^{\circ}$ 培養菌数に比べて江別地区 三 ルカー搾乳群を除く多くの例で少なく, また $20^{\circ}$ 培養菌 数に比べても大多数例で少なかった. $20^{\circ}$ 培養菌数では $35^{\circ}$ 培養菌数より多い例数の出現率が高かった.

3） 5 分離菌株では Pseudomonas, 大腸菌群, Flavobacterium などのグラム陰性桿菌類が全体の $80.8 \%$ を 占め, これらのグラム陰性桿菌類は $20^{\circ}$ 分離菌株でも全 体の $69.0 \%$ を占めた. $35^{\circ}$ 分離菌株では Streptococcus を主とする球菌類が $55.2 \%$ を占め, グラム陰性桿菌類は 30.7\%に過ぎなかった。

4） 4 種の温度での発育試験において，5分離菌株で は 1 株を除くすべてが $20^{\circ}$ で発育し，これらの大多数株 は良好飞発育した. $20^{\circ}$ 分離菌株では $5^{\circ}$ で $64.9 \%$ が， $35^{\circ}$ で84.8\%が発育した。また $35^{\circ}$ 分離菌株では5 ${ }^{\circ}$ で $21.5 \%$ が, $20^{\circ}$ で $95.9 \%$ が発育した。

5）以上の成績から， $20^{\circ} ， 4$ 日培養法は，工場生乳 中の低温細菌群検出の迅速法として役立つかるしれな い. また工場生乳中の生菌数の 推定には従来の $35^{\circ}, 2$ 日培養法より優れていると思われる。 
材料採取と生菌数測定には雪印乳業北海道本社, 江別 および札幌工場原料乳受入係, 同社勤務松山森一，神谷 秋良, 橋本 進, 金田昌晃, 小梁川則之, 吉田 巌の各 氏，酪農家の方々の御協力を得た. ここに厚く感謝す る.

\section{文献}

1）日越博信, 浜田輔一：食衛誌. 17, 27 (1976).

2) Desai, M. N., Claydon, T. J.: J. Milk Food Technol., 27, 333 (1964).

3) 白坂昭治, 久池井忠男：獣医畜産新報, 332,849 (1962).

4) 宮沢文雄, 野附 峳, 中野竜雄：食衛誌. 6, 242 (1965).

5）小川益男：東京農工大農学部学術報告, No. 11 ,
1 (1968).

6) Prouty, C. C.: J. Milk Food Technol., 18, 250 (1955).

7) Hartley, J.C., Vedamuthu, E. R., Reinbold, G.W., Clark, W.S. Jr.: ibid., 32, 37 (1969).

8) Witter, L.D.: J. Dairy Sci., 44, 983 (1961).

9) Thomas, S.B., Druce, R.G.: Dairy Inds., 34, 351, 430, 501 (1969).

10) Thomas, S. B.: ibid., 35, 79 (1970).

11) Thomas, S.B., Thomas, B.F.: ibid., 38, 61 (1973).

12) Panes, J. J., Thomas, S. B.: J. appl. Bact., 31, 420 (1968). 